\title{
FKBP5 wt Allele
}

National Cancer Institute

\section{Source}

National Cancer Institute. FKBP5 wt Allele. NCI Thesaurus. Code C105830.

Human FKBP5 wild-type allele is located in the vicinity of 6p21.31 and is approximately $155 \mathrm{~kb}$ in length. This allele, which encodes peptidyl-prolyl cis-trans isomerase FKBP5 protein, is involved in the modulation of protein folding. 